\title{
ASSESSMENT OF VERTEBRATE SPECIES DISTRIBUTION AND STATUS WITHIN FORT LARAMIE NATIONAL HISTORIC SITE
}

\author{
David M. Armstrong \\ University Museum and Natural Science Program \\ University of Colorado \\ Boulder
}

\section{Objectives}

The objectives of this on-going study are to: (1) develop a complete list of vertebrate species for Fort Laramie National Historic Site (FLNHS); (2) establish an information base on vertebrate populations; (3) identify threatened, endangered, and overpopulated species and recommend applicable management actions; and (4) assess the impact on wildlife populations of grazing by horses. Although these were recognized in advance as ambitious goals, each is, to some extent, being met.

\section{Methods}

Survey methods for mammals are those employed in a recently completed research in Devils Tower National Monument (Armstrong, 1987a). For small mammals, pairs of transects of livetraps were established in each major habitat-type (shortgrass prairie, riparian woodland, pastureland). Transects were run during each of three trapping periods for 4 days and nights without pre-baiting. Animals captured were identified to species, sexed, weighed, aged, their reproductive condition and microhabitat noted, individually marked (by toe-clipping), and then released. Numbers of animals per trapnight per species provides an index of relative abundance of species.

Reptiles, amphibians, and larger mammals (deer, lagomorphs, carnivores) are studied on $500 \mathrm{~m}$ belt transects laid out in each major habitat-type. Each transect is walked at least four times, making note of all vertebrates (or certain sign) seen in a band $5 \mathrm{~m}$. on either side of the line. Bats were captured by mist-netting in the riparian woodland. Birds are observed (visually or aurally) during 15-minute observation periods at fixed points chosen at random along belt transects. Fish were sampled by electrofishing. For any vertebrates of especially restricted occurrence, sketch maps will be prepared to indicate locations of sightings of animals or certain sign. These maps will be overlaid to provide a map of areas of critical wildlife habitat, if any.

In addition to the systematic sampling, note is being made of all other wildlife observed during the course of field survey and interested and knowledgeable Park Service personnel have been interviewed. 
Furthermore, historical literature, archives, and reports will be searched for references to native vertebrates.

Although field work has been coordinated with appropriate Park Service personnel and conducted as unobtrusively as possible, any field work attracts the attention of visitors. Therefore, a handout describing the survey was prepared and made available for distribution to interested persons. Field work in June, July, September, and December 1987 was conducted by the graduate research assistant, Rick A. Adams. Fish sampling in December was conducted by Aquatic and Wetland Consultants, Inc., of Boulder, Colorado. The author has been at Fort Laramie in December 1986 and in May, June, and August 1987.

\section{Results}

Results of work on small mammals are presented in Table 1. A total of 19 transects were run. Numbers of small mammals captured were low in initial livetrapping in June so assessment lines of snaptraps were set in August (see Armstrong, 1987b, 1987c). Preliminary analysis suggested no difference between live-trapping and snap-trap assessment lines.

Small mammal livetrapping provides our only quantitative data. In quarterly reports, qualitative documentation of vertebrates observed was tabulated in appendices. Table 2 summarizes observations to date. A total of 77 kinds of vertebrates have been observed, including 8 fishes, 3 amphibians, 2 reptiles, 47 birds, and 17 mammals. Table 2 indicates that 23 percent of the potential natural fauna (PNF) actually has been observed during the fieldwork. Given the fact that many of the species listed in the PNF would be expected only occasionally (and not as resident or breeding populations) on the National Historical Site, the rate at which species are being added to the list is gratifying.

FLNHS is an interesting area from several points of view. The valley of the North Platte River has provided a corridor not only for human movement across the Great Plains, but for the movement of the nonhuman biota as well. The riparian communities of the valley provide an important westward extension of the deciduous forest of the Midwest, a "peninsula" of eastern habitats surrounded by the shortgrass prairie of the uplands. The fauna of the "peninsula" appears to be in good condition, perhaps in part because the stability of riparian communities has been increased by control of floods and fires. Among species of the eastern deciduous forest observed at Fort Laramie are the eastern mole, Virginia opossum, white-tailed deer, red-headed woodpecker, and blue jay.

By contrast, the fauna of uplands appears to be in less satisfactory condition. Studies elsewhere in eastern Wyoming (e. g., Maxell and Brown, 1968) document thoroughly the fauna of shortgrass prairie. Most of the species expected have yet to be taken at Fort Laramie. The 
Table 1. Number of individual small mammals captured on transects in each of three major habitat-types.

\begin{tabular}{|c|c|c|c|c|c|c|c|c|c|}
\hline & & 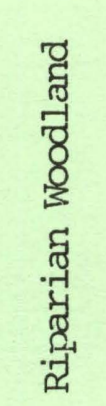 & & & 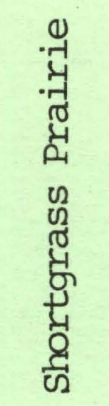 & & & 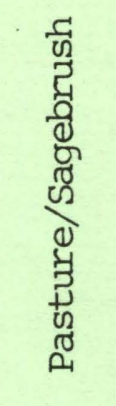 & \\
\hline & June & July & Sept & June & July & Sept & June & July & Sept \\
\hline $\begin{array}{l}\text { \# of Transects } \\
\text { (200 trap nights*) }\end{array}$ & 2 & 2 & 2 & 1 & 4 & 2 & 2 & 2 & 2 \\
\hline Deer Mouse & 4 & 2 & 2 & - & - & 6 & 2 & 2 & 1 \\
\hline Western Harvest Mouse & - & - & - & - & - & 1 & 1 & - & - \\
\hline Plains Harvest Mouse & - & - & - & - & - & - & - & - & 2 \\
\hline Prairie Vole & - & 1 & 4 & - & - & 3 & - & - & - \\
\hline
\end{tabular}

*Traps pulled after three nights if no captures recorded. 
Table 2. Summary of the potential natural vertebrate fauna (PNVF) and extent to which (PNVF) has been observed in the course of fieldwork in Fort Laramie National Historic Site.

\begin{tabular}{lccc}
\hline CLASS & $\begin{array}{c}\text { SPECIES IN } \\
\text { PNVF }\end{array}$ & $\begin{array}{c}\text { SPECIES } \\
\text { OBSERVED }\end{array}$ & \% OBSERVED \\
\hline OSTEICHTHYES & $15 *$ & $8 * *$ & 53 \\
AMPHIBIA & 6 & 3 & 50 \\
REPTILIA & 17 & 2 & 17 \\
AVES & 234 & 47 & 20 \\
MAMMAIIA & 58 & 17 & 29 \\
\hline TOTAL & 330 & 77 & 23.3 \\
* Plus three introduced species; * includes no introduced species.
\end{tabular}


plains harvest mouse has been captured; this often is a species of disturbed areas, including rocky pastures (see Jones et al., 1983). We have not observed such typical upland prairie species as ord's kangaroo rat, hispid or olive-backed pocket mice, 13-lined ground squirrels, or black-tailed prairie dogs. This is not particularly surprising. Old illustrations (see Mattes, 1980) show the environs of Fort Laranie essentially devoid of vegetation a century ago (see $x x x x x$ ). Other typical denizens of prairie dog towns (burrowing owls, prairie chickens, black-footed ferrets) also are missing. Grasslands surrounding the National Historic Site (from which colonists could re-invade reestablished shortgrass prairie habitats on the Historic Site) mostly are heavily grazed, industrialized, or plowed out for cropland.

Save ubiquitous deer of two species, larger mammals also are gone. Bison are present in Wyoming today only as fenced populations. Pronghorn are abundant throughout the grass and shrublands of Wyoming, but the National Historic Site is too small to support more than the occasionally wandering individual.

\section{Conclusions}

On-going studies of vertebrates at FLNHS re-emphasize the biogeographic interest of the North Platte Valley. Observations to date suggest that the fauna of riparian habitats probably reflects more accurately conditions of 100 to 150 years ago than does the fauna of upland habitats. Our final report will include some suggestions on how some missing components of the fauna might be re-established.

\section{Literature Cited}

Armstrong, D. M. 1987a. Baseline inventory of mammals, reptiles, and amphibians of Devils Tower National Monument, Wyoming. Final Rept. Processed report to Univ. of WY-Nat'l Park Serv. Res. Center, Laramie, 25 pp.

Armstrong, D. M. 1987b. Vertebrates of Fort Laramie National Historic Site. First Quarterly Rept. Processed report to Univ. of WY-Nat'1 Park Serv. Res. Center, Laramie, 14 pp.

Armstrong, D. M. 1987c. Vertebrates of Fort Laramie National Historic Site. Second Quarterly Rept. Processed report to Univ. of WYNat' 1 Park Serv. Res. Center, Laramie, 14 pp.

Jones, J. K., Jr., D. M. Armstrong, R. S. Hoffmann, and C. Jones. 1983. Mammals of the Northern Great Plains. Univ. NE Press, Lincoln, xii $+379 \mathrm{pp}$. 
Mattes, M. J. 1980. Fort Laramie Park history 1834-1977. Rocky Mtn Reg. Office, USDI-Nat'l Park Ser., Denver, xi + 382 pp. + 6 maps + 34 figures.

Maxell, M. H., and L. N. Brown. 1968. Ecological distribution of rodents on the High Plains of eastern Wyoming. Southwestern Nat., $13: 143-158$. 